\title{
RELIABILITY FOR ENGINEERS
}


Other Macmillan titles of related interest

Mechanical Reliability, 2nd edition, A. D. S. Carter

Reliability and Maintainability in Perspective, 2nd edition, D. J. Smith 


\title{
Reliability for Engineers
}

\author{
An Introduction
}

Eur Ing Michael Beasley

BSc (Hons), CEng, MIEE, FSaRS

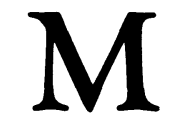

MACMILLAN 
(C) M. Beasley 1991

All rights reserved. No reproduction, copy or transmission of this publication may be made without written permission.

No paragraph of this publication may be reproduced, copied or transmitted save with written permission or in accordance with the provisions of the Copyright, Designs and Patents Act 1988 , or under the terms of any licence permitting limited copying issued by the Copyright Licensing Agency, 33-4 Alfred Place, London WC1E 7DP.

Any person who does any unauthorised act in relation to this publication may be liable to criminal prosecution and civil claims for damages.

First published 1991

Published by

MACMILLAN EDUCATION LTD

Houndmills, Basingstoke, Hampshire RG21 2XS

and London

Companies and representatives

throughout the world

British Library Cataloguing in Publication Data

Beasley, M.

Reliability for engineers.

1. Reliability engineering

I. Title 620.00452

ISBN 978-0-333-54238-5

DOI 10.1007/978-1-349-21369-6 
To my wife Frances and our children Ian and Susan 


\section{Contents}

Preface

viii

1 Introduction 1

2 Product Development 7

3 The Statistics of Failure - I 16

4 The Statistics of Failure - II 37

5 Component Reliability 61

6 System Reliability 75

7 Methods of Increasing System Reliability 91

8 Fault-tolerant Systems - I 95

9 Fault-tolerant Systems - II 102

10 The Behaviour of Maintained Systems 110

11 Elements of Markov Analysis 118

12 Spare Parts Provisioning 135

13 Software Reliability 143

14 Maintainability 153

15 System Reliability Prediction 161

16 Reliable Systems: Specification, Design, Manufacture and Installation 169

17 Reliability Growth 183

18 Reliability Demonstration 185

19 Some Analytical Methods and Computer Software 197

20 The Final Product $\quad 202$

21 References 204

22 Bibliography 207

23 Answers to Exercises $\quad 209$

Appendix 1: $\chi^{2}$ Distribution Tables for Even-numbered Degrees of Freedom

Appendix 2: 5\%, 95\%, and Median (50\%) Rank Tables 230

Appendix 3: The Elements of Probability Theory 242

Appendix 4: Glossary of Terms 253

Index 256 


\section{Preface}

This book is the outcome of lectures on reliability which I have given, firstly in-house in STC plc and later at Hatfield Polytechnic. It is intended to help both students who are new to the subject and practising engineers who are looking for help in reliability engineering.

Until my retirement I spent my working life in the telecommunications industry, and thus I had electrical engineers mostly in mind when writing this text. However, the theory and principles of reliability engineering are of wide applicability so that I hope this book will also be useful to workers in other engineering disciplines.

It is difficult, if not impossible, to learn reliability engineering in complete isolation. So my warm thanks go to all my former colleagues in STC plc who by discussions and instruction helped my understanding of the subject; in particular I should like to mention Dr G. G. Pullum, Mr G. H. P. Breuer and Mr I. Campbell.

I have also been greatly helped as a part-time lecturer at Hatfield Polytechnic by my colleagues Mr E. A. De Maria, Mr P. J. Bunn and Mr P. F. Jackson, to all of whom I owe a debt of gratitude.

There are already a number of good textbooks on reliability; my excuse for writing yet another is that I believe mine to be of practical help - to the student as well as to the qualified engineer.

I am grateful to Mrs D. J. Ross and Mrs S. M. Pilkington who typed early versions of the lecture notes from which this book has been developed; and also to my wife Frances who had the arduous task of typing most of the final manuscript.

Finally, it is a pleasure to express my thanks to Mr Malcolm Stewart and his colleagues of Macmillan Education Ltd for their help in bringing this book to press. 